\title{
CHROME FREE RAPID GLOVE LEATHER MANUFACTURE
}

\author{
Rajesh C M ${ }^{1} \mathbb{\text { iD }}$, Bharath Kumar G ${ }^{2}$ \\ 1,2 Department of Leather Technology, CSIR- Central Leather Research Institute, Chennai, Tamil \\ Nadu, India
}

DOI: https://doi.org/10.29121/granthaalayah.v9.i2.2021.3497

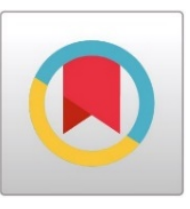

Article Type: Research Article

Article Citation: Rajesh C M, and Bharath Kumar G. (2021). CHROME FREE RAPID GLOVE LEATHER MANUFACTURE. International Journal of Research GRANTHAALAYAH, 9(2), 172-180. https://doi.org/10.29121/granthaa layah.v9.i2.2021.3497

Received Date: 07 January 2021

Accepted Date: 27 February 2021

Keywords:

Chrome Free

Glove Leather

Acrylic

\section{ABSTRACT}

In the current study, we use chrome free tanning process for the production of glove leather and to achieve the required properties without any compromising the quality. To develop a suitable post tanning system for making glove with good softness, run and strength properties. Glove leather predominantly made using chrome tanning system. Conventionally glove leather is done by long liming and ageing in pickling for better fibre splitting in order to achieve the run property. Production Time is very high due to long liming and ageing in pickling. Production cost can significantly reduce if the processing time for making glove is reduced. Acrylic followed by Glutaraldehyde combination tanning system adopted for chrome free tanning option. Long liming and ageing in pickle will be replaced with rapid fibre splitting process.

\section{INTRODUCTION}

A glove literally means "a cover" for hand with a sheath for each finger, but it is more than that. A good glove has to be a defense against cold and water, should maintain the body temperature and it should also leave the hand mobile enough to drive a vehicle, press a bomb button at the exact second, to grasp some heavy object lying underneath or to operate a machine etc. Leather is unique and ubiquitous, as old as man and yet modern. Leather contributes to a country's wealth. Leather is an international commodity and in spite of the severe competition from synthetics, the demand for the leather in the world shows a rising trend. So far, these substitutes have remained mainly as supplements. The inherent superiority of leather, rising population, higher incomes and leisure, new uses for leather, rapid changes in fashion snobbery and greater use of resources have all contributed to this continued demand for leather.

The demand for leatherwear has now been growing greater and greater. There is every indication that it will continue to do so for some more time. It is now an accepted fashion that leather is perfect material for all seasons and all moods. As atop fashion material, leather is used in the production of suits, coats, gloves, hats, ties etc. and it has now become a luxury material. The suppleness and wearability of glove leather in every color have captured the hearts of style conscious people everywhere. This raised demand for glove leather.

Chromium has been used as the primary tannage for many leathers for over 100 years. In the early days the tanning form, Cr (III), was produced from Cr (VI) in the form of Dichromate by reduction of the chrome in the tanning

(C) 2021 The Author(s). This is an open access article distributed under the terms of the Creative Commons Attribution License, which permits unrestricted use, distribution, and reproduction in any medium, provided the original author and source are credited. 
bath by sugars at low $\mathrm{pH}$. When basic chrome sulfate was introduced as a product ready to be used for tanning, tanneries changed to the use of these products either as an aqueous solution or as a dry product.

Environmental concerns about the effects of $\mathrm{Cr}(\mathrm{VI})$ and other heavy metals resulted in strict guidelines as to the amount of soluble chrome that could be discharged in a tannery waste stream and disposal of waste leather from shavings, trimmings and buffing dust was limited to contained landfills. There is no doubt that Cr (VI) compounds are both acutely and chronically toxic. The dose threshold effect for this element has not yet been determined accurately enough to allow regulations to be defined. However, some risks assessment analyses are currently being undertaken. $\mathrm{Cr}$ (III) is less toxic than some other elements ( $\mathrm{Hg}, \mathrm{Cd}, \mathrm{Pb}, \mathrm{Ni}, \mathrm{Zn}$ ) to mammalian and aquatic organism. Probably due to the low solubility of this elements in its trivalent form. Compared to $\mathrm{Cr}$ (VI), the toxicity of Cr (III) is insignificant. Hexavalent Chromium has been proven to carcinogenic and causes damage to skin. Mucous membrane, respiratory tract, Kidney, etc. It has also been shown that there are some possibilities for the formation of chromium (VI) during processing conditions (IS-2490/1985) Recent reports suggest that higher levels and under certain ligand environments chromium (III) also toxic. The Problem is aggregated by the fact that the currently practiced chrome tanning procedures lead to an uptake of only 60-65o of the chrome offered by leather and hence substantial amount of chrome is discharged into the effluents.

Even, so the possibility of oxolation of chrome in the landfill to $\mathrm{Cr}$ (VI) with leaching into the environment has been a concern to Environmental Protection Agencies (EPA). However, the disposal of leather from worn-out shoes, garments, Glove, Upholstery and the possibilities of ingestion of chrome tanned leather by children has been addressed only recently.

\section{MATERIALS AND METHODS}

\subsection{STANDARDISATION OF TANNING SYSTEM}

Wet salted sheep skins of uniform size and weight were taken and processed into chrome free tanning system using Acrylic followed by glutaraldehyde tanning system. The control process for gloving and the process developed with alternate tanning system are shown table, three wet slated skins (processed as mentioned in Table 2.1) of 5 sq. $\mathrm{ft}$ (average) were used for the experiments. Each wet salted skin was used for each experimental trial.

\subsubsection{SELECTION/STANDARTISATION OF POST TANNING SYSTEM}

Wet salted sheepskins of uniform size and weight were taken and processed into Chrome free tanning using process shown in Table 2.1. The post tanning trials was carried out to select suitable fatliquors and retanning agents to obtain glove leather with high run, strength and softness properties.

\subsubsection{SELECTION OF SUITABLE FATLIQUOR}

Six fatliquors of different bases were screened for glove leather manufacture. The chosen Fatliquor and their base are shown. Two experimental trials varying the combination of fatliquors have been carried out. The experimental trials on Fatliquor are shown.

Fatliquor screened for experiment on glove leather manufacture

\begin{tabular}{|c|c|c|}
\hline S.NO & Name of fatliqour & Nature \\
\hline 1 & Balmol BLSFO & Sulphited fish oil based Fatliquor \\
\hline 2 & Balmol SX-20 & Synthetic based Fatliquor \\
\hline 3 & Balmol SX-25 & Sulphited natural oil based Fatliquor \\
\hline 4 & Lipoderm liquor LP-16 & Lecithin based Fatliquor \\
\hline 5 & Vicastol SP & Sulpho chlorinated paraffin wax \\
\hline 6 & Vicastol WGF & Synthetic lanoline based Fatliquor \\
\hline
\end{tabular}




\subsection{PHYSICAL TESTING AND HAND EVALUATION OF LEATHER}

Samples for various physical tests from experiments and control crust leathers were obtained as per IUP methods (IUP2 2000). Specimens were conditioned at $80 \pm 4^{\circ} \mathrm{O}$ and $65 \pm 2 \%$ R.H. over a period of 48 hrs. Physical properties such as tensile strength, tear strength and \% elongation at break were examined as per the standard procedures (IUP6 2000, IUP8 2000). Crust leathers were assessed for softness, fluffiness, grain smoothness and general appearance by hand and visual examination. Experienced tanners rated the leathers on a scale of 1-10 points for each functional property, where high points indicate better property.

\subsubsection{RUN MEASUREMENT}

Run is measured in the following manner. The leather is first stretched lengthwise. In this condition breath wise length of the leather was measured. It was taken as initial length. Then the leather was stretched in breadthwise direction and the stretched breath wise length was found. Difference between the stretched and initial length is a measure of "Run". Similarly, for determining the run in the lengthwise direction, the leather was stretched first in the breath wise direction. The length was measured lengthwise (initial length). Then the leather was stretched in the lengthwise direction. The length of the leather in the stretched condition is measured. Difference of the lengths is a measure of "Run".

$$
\% \text { Run }=\frac{(\text { Stretched length }- \text { Initial length })}{\text { Initial length }} \times 100
$$

Run measurements in the case of quarter pieces shown in Figure 2.7 is carried(stretched) at line (perpendicular to backbone) $30 \%$ of distance L from the centre point A. Similar methodology is adopted for run measurement of all quarter pieces. In the case of half and full pieces run measurements were made at centre position (perpendicular to the backbone) of the total length of the backbone.

\subsubsection{SOFTNESS}

Softness of the leather was measured using ST300 Digital leather softness tester. The ST300 D is a means of determining the softness of leather without defacing the hide or skin, as it does not require samples to be cut from the leather prior to testing. But the experimental and control crust leathers were conditioned at $80 \pm 4{ }^{\circ} \mathrm{F}$ and $65 \pm 2 \%$ R.H. over a period of $48 \mathrm{hrs}$. The softness of the experimental sample was noted directly after fixing it to the ST300 Digital leather softness tester. This device has now been adopted as the industry standard by IULTCS (IUP 36).

\subsubsection{STRENGTH MEASUREMENT}

\subsubsection{TENSILE STRENGTH \& ELONGATION AT BREAK}

Tensile strength is the force $(\mathrm{kg})$ per unit area of the cross section (sq.cm) required to cause the rupture of the specimen. Dumbbell shaped specimen, of required shape and size are cut both at the parallel and the perpendicular direction of the back bone of experimental and control crust leathers were obtained as per IULTCS methods (IUP 6) and conditioned at $80 \pm 4 \% \mathrm{~F}$ and $65 \pm 2 \%$ R.H. over a period of $48 \mathrm{hrs}$. Width and thickness of the specimen, at not less than 3 places are measured and the average value is noted. Set the jaws of the tensile tester apart for each sample respectively. Clamp the test specimen in the jaws and run the machine at the rate of $100 \pm 2 \mathrm{~mm} / \mathrm{min}$ until the specimen breaks. Note the distance between the jaws when rupture of the test specimen occurred.

\subsubsection{TEAR STRENGTH}

Tear strength is the load (kg) required to tear the leather beyond the cut made perpendicular to its surface, expressed per unit thickness. Specimen of required shape and size are cut both at the parallel and the perpendicular direction of the back bone of experimental and control crust leathers were obtained as per IULTCS methods (IUP 8) 
and conditioned at $80 \pm 4 \% \mathrm{~F}$ and $65 \pm 2 \%$ R.H. over a period of $48 \mathrm{hrs}$. Thickness of the specimen is noted. Insert the slot of the specimen into the test piece holder fixed to the tensile tester. Run the tester at the rate of $100 \pm 2 \mathrm{~mm} / \mathrm{min}$ until the specimen is torn apart.

\subsubsection{GRAIN BURST LOAD AND DISTENSION (LASTOMETER TEST)}

Circular leather pieces $(44.5 \mathrm{~mm}$ ) from the experimental and control crust leathers were obtained as per IULTCS methods (IUP 12) and conditioned at $80 \pm 4 \mathrm{o} F$ and $65 \pm 2 \%$ R.H. over a period of 48 hrs. Clamp the test specimen tightly in the lastometer and force the plunger at a rate of $0.20 \pm 0.05 \mathrm{~mm} / \mathrm{second}$. When the burst appears note down the force and distention

\section{RESULTS AND DISCUSSIONS}

\subsection{EFFECT OF UREA TREATMENT}

The experimental trials have been conducted using 3\% urea treatment before tanning. The tear strength, softness is good. From the literature table it is observed that usage of $3 \%$ urea in pretanning results in maximum run property around 35\%, with further increase in urea the \%run is found to decrease. Urea is a well-known protein secondary structure destabilizer, beyond a certain concentration they may affect the structure of the collagen matrix significantly because of rupturing protein, which may result in lowering of run. But in our experiments, it Shows better results which had given $35 \%$ and $20 \%$ run.

\subsection{EFFECT OF FATLIQUORS ON GLOVING PROPERTIES}

Six different bases of fatliquor have been screened. Since fish oil is known to posses' very good lubricating ability, a fatliquor based on fish oil is very essential for glove leather. Hence, sulfited fish oil fatliquor (Sfo) has been offered for all experimental trails. Trials have been carried out with varying the combination of other five fatliquors as mentioned. The run, softness, visual assessment data for leather processed using different combination of fatliquor is shown

\section{Control}

\begin{tabular}{|c|c|c|c|c|}
\hline Process & Chemicals & $\begin{array}{c}(\% \\
\text { Offer })\end{array}$ & Time & Remarks \\
\hline Washing & Water & 100 & 10 mins & \\
\hline \multirow[t]{2}{*}{ Deliming } & Water & 100 & & \multirow{2}{*}{$\begin{array}{l}\text { Completion was checked by } \\
\text { Phenolphthalein }\end{array}$} \\
\hline & $\begin{array}{l}\text { Ammonium } \\
\text { Chloride }\end{array}$ & 3 & 60 mins & \\
\hline Washing & Water & 100 & 10 mins & \multirow{3}{*}{ Air bubble to check the completion } \\
\hline \multirow[t]{2}{*}{ Bating } & Water & 100 & & \\
\hline & Microbate-R & 0.5 & 60 mins & \\
\hline Washing & Water & 100 & 10 mins & \\
\hline \multirow[t]{2}{*}{ Degreasing } & Water & 100 & & \\
\hline & VDG & 1 & 60 mins & \\
\hline Washing & Water & 100 & 10 mins & \\
\hline \multirow[t]{4}{*}{ Pickling } & Water & 100 & & \multirow[t]{4}{*}{ Check the $\mathrm{pH} 2.8-3.0$ and drain $1 / 3 \mathrm{rd}$ of pickle liquor } \\
\hline & $\begin{array}{c}\text { Sodium } \\
\text { Chloride }\end{array}$ & 10 & & \\
\hline & Water & 10 & & \\
\hline & Sulphuric Acid & 1 & $\begin{array}{c}4 \times 5 \\
60 \text { mins }\end{array}$ & \\
\hline
\end{tabular}


Chrome Free Rapid Glove Leather Manufacture

\begin{tabular}{|c|c|c|c|c|}
\hline \multirow{3}{*}{$\begin{array}{c}\text { Tanning } \\
\text { Control }\end{array}$} & & & & \\
\hline & Water & 50 & & \multirow[t]{2}{*}{ Check cross section for penetration } \\
\hline & BCS & 5 & 60 mins & \\
\hline \multirow[t]{3}{*}{ Basification } & $\begin{array}{l}\text { Sodium } \\
\text { Formate }\end{array}$ & 1 & & \multirow[t]{3}{*}{ Check the pH 3.8-4.2 and ageing for 24 hours } \\
\hline & Water & 10 & & \\
\hline & $\begin{array}{c}\text { Sodium } \\
\text { bicarbonate }\end{array}$ & 1 & $\begin{array}{l}4 \times 5 \\
60 \text { mins }\end{array}$ & \\
\hline
\end{tabular}

Experiment 1

\begin{tabular}{|c|c|c|c|c|}
\hline Process & Chemicals & $\begin{array}{c}(\% \\
\text { Offer })\end{array}$ & Time & Remarks \\
\hline Washing & Water & 100 & $\begin{array}{c}10 \\
\text { mins }\end{array}$ & \\
\hline \multirow[t]{2}{*}{ Deliming } & Water & 100 & & \multirow[t]{2}{*}{$\begin{array}{c}\text { Completion was checked by } \\
\text { Phenolphthalein }\end{array}$} \\
\hline & $\begin{array}{l}\text { Ammonium } \\
\text { Chloride }\end{array}$ & 3 & $\begin{array}{c}60 \\
\text { mins }\end{array}$ & \\
\hline Washing & Water & 100 & $\begin{array}{c}10 \\
\text { mins }\end{array}$ & \\
\hline \multirow[t]{2}{*}{ Bating } & Water & 100 & & \multirow[t]{2}{*}{ Air bubble to check the completion } \\
\hline & Microbate-R & 0.5 & $\begin{array}{c}60 \\
\text { mins }\end{array}$ & \\
\hline Washing & Water & 100 & $\begin{array}{c}10 \\
\text { mins }\end{array}$ & \\
\hline \multirow[t]{6}{*}{$\begin{array}{c}\text { Urea } \\
\text { Treatment } \\
\end{array}$} & Water & 100 & & \\
\hline & Urea & 3 & $\begin{array}{c}120 \\
\text { mins }\end{array}$ & pH 7.0 \\
\hline & $\begin{array}{l}\text { Sulfone based } \\
\text { syntan }\end{array}$ & 2 & $\begin{array}{c}120 \\
\text { mins }\end{array}$ & pH 6.0 \\
\hline & Needs foot oil & 2 & $\begin{array}{c}2 \times 5 \\
45 \\
\text { mins } \\
\end{array}$ & \\
\hline & GT-50 & 2 & $\begin{array}{c}120 \\
\text { mins }\end{array}$ & pH 5.0 \\
\hline & $\begin{array}{l}\text { Electrostatic stable } \\
\text { fatliquor }\end{array}$ & 2 & $\begin{array}{l}2 \times 10 \\
60 \\
\text { mins }\end{array}$ & Check for the penetration and pile overnight \\
\hline
\end{tabular}

\section{Experiment 2}

\begin{tabular}{|c|c|c|c|c|}
\hline Process & Chemicals & $\begin{array}{c}(\% \\
\text { Offer }\end{array}$ & Time & Remarks \\
\hline Washing & Water & 100 & $\begin{array}{c}10 \\
\text { mins }\end{array}$ & \\
\hline Deliming & Water & 100 & $\begin{array}{c}\text { Completion was checked by } \\
\text { Phenolphthalein }\end{array}$ \\
\cline { 2 - 4 } & $\begin{array}{c}\text { Ammonium } \\
\text { Chloride }\end{array}$ & 3 & $\begin{array}{c}60 \\
\text { mins }\end{array}$ & \\
\hline
\end{tabular}


Rajesh C M, and Bharath Kumar G

\begin{tabular}{|c|c|c|c|c|}
\hline Washing & Water & 100 & $\begin{array}{c}10 \\
\text { mins }\end{array}$ & \\
\hline \multirow[t]{2}{*}{ Bating } & Water & 100 & & \multirow[t]{2}{*}{ Air bubble to check the completion } \\
\hline & Microbate-R & 0.5 & $\begin{array}{c}60 \\
\text { mins }\end{array}$ & \\
\hline Washing & Water & 100 & $\begin{array}{c}10 \\
\text { mins }\end{array}$ & \\
\hline \multirow[t]{7}{*}{$\begin{array}{c}\text { Urea } \\
\text { Treatment } \\
\end{array}$} & Water & 100 & & \\
\hline & Urea & 3 & $\begin{array}{c}120 \\
\text { mins }\end{array}$ & pH 7.0 \\
\hline & $\begin{array}{c}\text { Sulfone based } \\
\text { syntan }\end{array}$ & 2 & $\begin{array}{c}120 \\
\text { mins }\end{array}$ & pH 6.0 \\
\hline & Needs foot oil & 2 & $\begin{array}{c}2 \times 5 \\
45 \\
\text { mins } \\
\end{array}$ & \\
\hline & Acrylic syntan & 2 & $\begin{array}{c}60 \\
\text { mins }\end{array}$ & pH 5.5 \\
\hline & GT-50 & 2 & $\begin{array}{c}120 \\
\text { mins }\end{array}$ & pH 5.0 \\
\hline & $\begin{array}{l}\text { Electrostatic stable } \\
\text { fatliquor }\end{array}$ & 2 & $\begin{array}{c}2 \times 10 \\
60 \\
\text { mins }\end{array}$ & Check for the penetration and pile overnight \\
\hline
\end{tabular}

\subsection{INTEGRATION OF BEST TANNING SYSTEM ALTERNATE TO THE CHROME AND POST-TANNING SYSTEMS FOR GLOVE LEATHER}

Experimental trials have been carried out by integrating the treatment of $4 \%$ urea treatment before tanning along with the $2 \%$ of acrylic and GT-50 at Tanning and best post tanning practices i.e., usage of 4 fatliquors $4 \%$ amount each and FB-6 syntans for retanning. The run and other properties of the leathers are given in the table it is clear that the urea treatment has helped to improve the run property of glove to the levels equivalent to run of leathers.

Post tanning process

Control

\begin{tabular}{|c|c|c|c|c|}
\hline Process & Chemicals & (\% Offer) & Time & Remarks \\
\hline Washing & $\begin{array}{c}\text { Water } \\
\text { Wetting agent } \\
\text { Degreasing agent }\end{array}$ & $\begin{array}{l}200 \\
0.3 \\
0.2\end{array}$ & 30 mins & \\
\hline Rechroming & $\begin{array}{c}\text { Water } \\
\text { Formic acid } \\
\text { Noval Tan PF } \\
\text { BA } \\
\text { BCS } \\
\text { Fish oil } \\
\text { Water } \\
\text { Sodium acetate } \\
\text { Sodium bicarbonate }\end{array}$ & $\begin{array}{c}100 \\
0.3 \\
1 \\
1 \\
4 \\
1 \\
100 \\
1 \\
0.75 \\
\end{array}$ & $\begin{array}{c}2 \times 10+30 \mathrm{mins} \\
10 \mathrm{mins} \\
10 \mathrm{mins} \\
60 \mathrm{mins} \\
15 \mathrm{mins} \\
\\
20 \mathrm{mins} \\
60 \mathrm{mins} \\
\end{array}$ & Check pH 2.8-3.0 \\
\hline Neutralization & $\begin{array}{c}\text { Water } \\
\text { Sodium formate } \\
\text { Fish oil } \\
\text { Sodium bicarbonate }\end{array}$ & $\begin{array}{c}100 \\
1 \\
0.5 \\
1\end{array}$ & $\begin{array}{c}20 \text { mins } \\
10 \text { mins } \\
2 \times 10+60 \text { mins }\end{array}$ & Check pH 6.0 \\
\hline
\end{tabular}


Chrome Free Rapid Glove Leather Manufacture

\begin{tabular}{|c|c|c|c|c|}
\hline Retanning & $\begin{array}{c}\text { Water } \\
\text { ASR } \\
94 S \\
\text { MAP } \\
\text { VOS } \\
\text { Novel Tan PF } \\
\text { Dye }\end{array}$ & $\begin{array}{c}100 \\
2 \\
2 \\
1.5 \\
2 \\
1 \\
2\end{array}$ & $\begin{array}{l}20 \text { mins } \\
20 \text { mins } \\
10 \text { mins } \\
20 \text { mins } \\
45 \text { mins }\end{array}$ & Check for penetration \\
\hline Fat liquor & $\begin{array}{c}\text { BA } \\
94 S \\
\text { Fish oil } \\
\text { MBS } \\
\text { Soft styrene }\end{array}$ & $\begin{array}{c}1 \\
2 \\
1 \\
2 \\
0.5\end{array}$ & $\begin{array}{l}60 \text { mins } \\
15 \text { mins }\end{array}$ & \\
\hline Fixing & Formic Acid & 3 & $3 \times 10+60 \mathrm{mins}$ & \\
\hline
\end{tabular}

Experiment 1

\begin{tabular}{|c|c|c|c|c|}
\hline Process & Chemicals & (\% Offer) & Time & Remarks \\
\hline Washing & $\begin{array}{c}\text { Water } \\
\text { Wetting agent }\end{array}$ & $\begin{array}{c}200 \\
0.3\end{array}$ & 30 mins & \\
\hline Neutralization & $\begin{array}{c}\text { Water } \\
\text { Neutralizing syntan } \\
\text { Sodium formate } \\
\text { Sodium bicarbonate }\end{array}$ & $\begin{array}{c}100 \\
1 \\
1 \\
1\end{array}$ & $\begin{array}{c}45 \text { mins } \\
10 \text { mins } \\
2 \times 10+60 \text { mins }\end{array}$ & Check pH 6.5 \\
\hline Pre fat liquor & $\begin{array}{c}\text { Water } \\
\text { Balmol SX } 100 \\
\text { Lipoderm liquor }\end{array}$ & $\begin{array}{c}100 \\
3 \\
3\end{array}$ & 60 mins & \\
\hline Retanning \& Fat liquor & $\begin{array}{c}\text { Water } \\
\text { Melamine syntan } \\
\text { Dye } \\
\text { Balmol BLSO } \\
\text { Balmol SX 25 } \\
\text { Balmol SX } 20 \\
\text { Lipoderm liquor }\end{array}$ & $\begin{array}{c}100 \\
1.5 \\
3 \\
2 \\
4 \\
4 \\
2\end{array}$ & $\begin{array}{l}20 \text { mins } \\
20 \text { mins } \\
10 \text { mins } \\
20 \text { mins } \\
45 \text { mins }\end{array}$ & Check for penetration \\
\hline Fixing & $\begin{array}{c}\text { Water } \\
\text { Formic Acid }\end{array}$ & $\begin{array}{c}10 \\
3\end{array}$ & $3 \times 10+60$ mins & \\
\hline
\end{tabular}

Experiment 2

\begin{tabular}{|c|c|c|c|c|}
\hline Process & Chemicals & (\% Offer) & Time & Remarks \\
\hline Washing & Water & 200 & & \\
& Wetting agent & 0.3 & 30 mins & \\
\hline Neutralization & Water & 100 & & \\
& Neutralizing syntan & 1 & 45 mins & \\
& Sodium formate & 1 & 10 mins & Check pH 6.5 \\
& Sodium bicarbonate & 1 & $2 \times 10+60$ mins & \\
& & & & \\
& & & & \\
& & & & \\
\hline
\end{tabular}


Rajesh C M, and Bharath Kumar G

\begin{tabular}{|c|c|c|c|c|}
\hline Pre fat liquor & $\begin{array}{c}\text { Water } \\
\text { Balmol SX } 100 \\
\text { Lipoderm liquor }\end{array}$ & $\begin{array}{c}100 \\
3 \\
3 \\
\end{array}$ & 60 mins & \\
\hline Retanning \& Fat liquor & $\begin{array}{c}\text { Water } \\
\text { Melamine syntan } \\
\text { Dye } \\
\text { Balmol BLSO } \\
\text { Balmol SX 25 } \\
\text { Balmol SX 20 } \\
\text { Lipoderm liquor }\end{array}$ & $\begin{array}{c}100 \\
1.5 \\
3 \\
2 \\
4 \\
4 \\
2\end{array}$ & $\begin{array}{l}20 \text { mins } \\
20 \text { mins } \\
10 \text { mins } \\
20 \text { mins } \\
45 \text { mins }\end{array}$ & Check for penetration \\
\hline Fixing & $\begin{array}{c}\text { Water } \\
\text { Formic Acid }\end{array}$ & $\begin{array}{c}10 \\
3\end{array}$ & $3 \times 10+60$ mins & \\
\hline
\end{tabular}

Table 3.1: Strength measurements of glove leathers

\begin{tabular}{|c|c|c|c|c|c|}
\hline SAMPLE & $\begin{array}{c}\text { Tear } \\
\text { strength } \\
\text { Kg/cm }\end{array}$ & $\begin{array}{c}\text { Tensile Strength } \\
\mathrm{kg} / \mathrm{cm} 2\end{array}$ & $\begin{array}{c}\text { \%ELONGATION AT } \\
\text { BREAK }\end{array}$ & $\begin{array}{c}\text { LOAD AT GRAIN } \\
\text { BURST kg }\end{array}$ & $\begin{array}{c}\text { DISTENTION AT } \\
\text { GRAIN BURST } \\
\text { Mm }\end{array}$ \\
\cline { 2 - 6 } & Average & Average & Average & Load & Distention \\
\hline Control & 33.40 & 26.80 & 72.65 & 20 & 14.38 \\
\hline E1 & 28.90 & 15.41 & 41.50 & 22 & 11.84 \\
\hline E2 & 32.45 & 21.65 & 44.00 & 17 & 13.10 \\
\hline
\end{tabular}

\section{CONCLUSIONS AND RECOMMENDATIONS}

The chrome free glove leather produces lesser effluent discharge when compared to conventional process. Lecithin based fat liquor is found to improve the softness and run property of glove leather, synthetic fat liquor is found to improve the tear strength property .4\% fat liquor each of LP-16, SX-20, SX-25 has been found to be the better combination of fat liquors for good gloving properties. Syntans of $2 \%$ offer of DLE and FB- 6 have been found to be the optimum amounts. Ageing after pickling have been found to enhance the run property of the glove leathers. 3\% Urea pretreatment before glutaraldehyde tanning has been found to be effective which result in glove leather with superior run and strength property, integration of pretreatment of skin with urea followed by glutaraldehyde tanning and post tanning with optimized post tanning practices have resulted in better glove leathers compared to the conventional process.

\section{SOURCES OF FUNDING}

This research received no specific grant from any funding agency in the public, commercial, or not-for-profit sectors.

\section{CONFLICT OF INTEREST}

The author have declared that no competing interests exist.

\section{ACKNOWLEDGMENT}

CSIR-CLRI R/2021/SDC/MLP/1525. 


\section{REFERENCES}

[1] Bower J.H.relation between Run \& Physical properties JSLT 26,181,1942

[2] Fein M.L.Viola s,J.Luvisi,fop.naghski J.A rapid test for resistance of glove leather to perspiration -technical note JALCA $67,136,1972$

[3] Ferd 'o' Flaherty the chemistry \& technology of leather manufacture vol-2 Newyork, 1972

[4] Viola Fein m.l.nag ski j,washablity of gluteraldehyde-chrome tanned garment \& glove leather-JALCA

[5] Iup 2 sampling JSLTC 84,303-309,2000

[6] Iup 6 measurement of Tensile strength \& \% of elongation at break, JSLTC 84,317,2000

[7] Iup 8 measurement of Tear load JSLTC 84,327,2000

[8] Iup 36 measurement of softness Jlstc 84,317,2000

[9] Glove leather manufacture from sheep skins: Influence of fatliqours and Syntans on the gloving properties, JALCA 103, 182-200,2008

[10] Process for Manufacturing of glove leather from sheep from industry (NRS CHEMI SERVICES) Vaniyambadi.

[11] Wolf G, Breth M, Igl G (2001) J Am Leather Chemists Assoc 96:111

[12] Palop R (2003) Leather International, May 2003, 27-33

[13] Schwaiger W (2001) Leather International, July 2001, 28-30

[14] Fennen J (2003) 99th American Leather Chemist Association annual meeting, June 2003, 19-22

[15] Liu C-K, Latona NP, Lee J (2005) J Am Leather Chemists Assoc 100:8

[16] Liu C-K, Latona NP (2006) J Am Leather Chemists Assoc 101:330

[17] Liu C-K, Latona NP, Lee J (2005) J Am Leather Chemists Assoc 100:102

[18] Liu C-K, Latona NP, Cooke P (2007) J Am Leather Chemists Assoc 102:68

[19] Liu C-K, Dimaio GL (2000) J Am Leather Chemists Assoc 95:102

[20] Liu C-K, Dimaio GL (2001) J Am Leather Chemists Assoc 96:243

[21] Liu C-K, Latona NP, Dimaio GL (2002) J Am Leather Chemists Assoc 97:284

[22] Liu C-K, Latona NP, Dimaio GL (2002) J Am Leather Chemists Assoc 96:243. 